\author{
Sławoj Tanaś \\ Uniwersytet Łódzki \\ Katedra Geografii Miast i Turyzmu \\ 90-142 Łódź, ul. Kopcińskiego 31 \\ tel. 048426354555 \\ slatan@geo.uni.lodz.pl
}

\section{ZNACZENIE PRZESTRZENI ŚMIERCI W TURYSTYCE KULTUROWEJ}

W procesie kształtowania przestrzeni turystycznej istotną rolę odgrywają walory turystyczne, będące zespołem elementów środowiska naturalnego oraz pozaprzyrodniczego i stanowiące o stopniu naszego zainteresowania turystycznego określoną przestrzenią. W wymiarze poznania zainteresowanie to i zakres naszej wrażliwości w znacznym stopniu określa kultura, dzięki której nadajemy znaczenie wydarzeniom, miejscom i przestrzeniom. Tym samym szeroko pojęta kultura, rozumiana jako całokształt materialnego i duchowego dorobku ludzkości, wytworzonego w ogólnym rozwoju historycznym lub w jego określonej epoce, stanowiąca całość złożoną z norm, symboli, mitów, obrazów oraz nadająca kierunek uczuciom, zainteresowaniom i czynom ma wpływ na powstanie i charakter przestrzeni turystycznej. Kultura, która stanowić może obiekt zainteresowań turysty (np. walory kulturowe, krajoznawcze), decyduje jednocześnie o charakterze tych zainteresowań.

Jednym ze stałych elementów kultury jest śmierć i jej semiotyka, która wzbudza w człowieku jednocześnie przerażenie i ciekawość. Percepcja śmierci, grobu i cmentarza jest odmienna w różnych kręgach kulturowych i ulegała przemianom wraz z rozwojem cywilizacyjnym świata. Różnice kulturowe, religijne i światopoglądowe zachęcają do odbywania podróży poznawczych, w ramach których może pojawić się zainteresowanie śmiercią i potrzeba odwiedzenia przestrzeni śmierci (np. cmentarza, grobu, wystawy). Turystyka jest formą odnajdywania śladów przeszłości, nierozłącznie związanych $\mathrm{z}$ upływającym czasem, a więc i śmiercią.

Wyodrębniona z przestrzeni społeczno-geogra-

\section{THE MEANING OF DEATHSPACE IN CULTURAL TOURISM}

Tourism assets, which are elements of natural and non-natural environments and determine our interest in a given space, play an important role in the process of creating tourism space. This interest and our sensitivity are largely determined by culture which allows us to see the meaning of events, places and spaces. Culture is understood as the whole of the material and spiritual output of humanity produced during general historical development or in a given epoch, and consisting of norms, symbols, myths and images which determine our feelings, interests and actions. It has an influence on the creation and character of tourism space. Culture, which may be the object of a tourist's interest (e.g. cultural or landscape assets), determines its character too.

One permanent element of culture is death, and its semiotics makes us both terrified but curious at the same time. The perception of death, the grave and the cemetery differs in different cultural environments and it has evolved along with the developments in civilization globally. Cultural, religious and other differences of opinion encourage people to go on journeys during which there may be an interest in death, followed by the need to visit a deathspace (e.g. a cemetery, a grave or a tombstone). Tourism is a form of search for traces of the past which show the passing of time and, consequently, 
ficznej przestrzeń śmierci obejmuje przede wszystkim przestrzeń grzebalną (groby, cmentarze), zwaną przestrzenią sepulkralną. Jest to jednak bardzo wąskie rozumienie tego pojęcia. Przestrzeń śmierci (sensu largo) to przestrzeń związana ze śmiercią np. jej aktem, miejscem, formą upamiętnienia, obrzędami i wierzeniami, symboliką, krajobrazem, wydarzeniem, etc. Interpretacja przestrzeni śmierci zależy m.in. od osobowości, postaw, kultury, percepcji, motywacji czy emocji.

Cmentarz w swej symbolice, zależnej od specyfiki kulturowej danej społeczności, nadaje określony charakter krajobrazowi i stanowi jego istotną część. Większość współczesnych krajobrazów cmentarzy jest konsekwencją rozchodzenia się i przenoszenia elementów kultury w drodze zapożyczenia, a więc dyfuzji (np. cmentarze europejskie), następstwem czego może być synkretyzm krajobrazu cmentarzy (np. cmentarze meksykańskie). Badania nad interpretacją kulturowego krajobrazu cmentarza prowadzone były w II połowie XX w. przede wszystkim w Stanach Zjednoczonych i Wielkiej Brytanii.

Opisując znaczenie przestrzeni śmierci w turystyce kulturowej należy wspomnieć o dorobku badawczym geografii w omawianym zakresie, który ma istotne znaczenie $\mathrm{w}$ interpretowaniu turystycznego charakteru krajobrazów cmentarzy, np. w geografii turyzmu (TANAŚ 2004). Badania geografów nad przestrzenią śmierci (deathspace), przestrzenią umarłych (deadspace) i krajobrazem śmierci (deathscape) mają swój początek w amerykańskiej szkole nekrogeografii, której twórcą był KNIFFEN (1967). Nekrogeografia to studia nad morfologią cmentarzy, będących odbiciem realnego świata (FrancAVIGLIA 1971). Jednym z jej głównych problemów badawczych jest emocjonalny (sacrum) i funkcjonalny (profanum) sens cmentarza jako wspólnej przestrzeni żywych i umarłych. Cmentarz jest analizowany jako krajobraz kulturowy o określonych, indywidualny cechach i formach (plan, grobowce, pomniki, ogrodzenie, roślinność).

Na przełomie XVIII i XIX w. rodząca się turystyka odkrywała dziedzictwo kulturowe świata. Turyści odkrywali, często na nowo, obiekty historyczne i religijne. XIX w. przyniósł również zainteresowanie przestrzeniami śmierci. Fakt ten wynikał z dokonujących się zmian w postawie człowieka Zachodu wobec śmierci (ARIES 1989).

Utracony w średniowieczu kult zmarłego, który pojawił się ponownie w Europie pod koniec wieku XVIII, doprowadził do zmian w nastawieniu człowieka do śmierci, grobu i cmentarza. Przestrzenie death.

A part of socio-geographical space, deathspace mostly concerns that part of burial space (graves, cemeteries) known as sepulchral space. This, however, is a very narrow meaning of the term. Deathspace (sensu largo) is any space related to death e.g. the very act of dying, the place, the form of commemoration, rituals and beliefs, symbolism, landscape etc. The interpretation of deathspace depends on personality, attitudes, culture, perception, motivation and emotion.

The cemetery and its symbolism, dependent on the specific culture of a given community, imposes a particular character on the landscape and is an important part of it itself. The majority of contemporary deathscapes are a consequence of spreading and transferring elements of culture via diffusion (e.g. European cemeteries) which can result in deathscape syncretism (e.g. Mexican cemeteries). Research into the interpretation of cultural deathscapes was conducted in the first half of the 20th c., mostly in the USA and Great Britain.

While discussing the meaning of deathspace in cultural tourism, we must mention the geographical research which plays an important role in the interpretation of the tourism character of deathscapes e.g. tourism geography (TANAŚ 2004). Geographical research into deathspace, deadspace and deathscape originated in an American school of necrogeography, created by KNIFFEN (1967). Necrogeography is a study of cemetery morphology; cemeteries are a reflection of real life (FRANCAVIGLIA 1971). One of its main themes is the sacrum and profanum of the cemetery, as a space that the dead and the living share. The cemetery is analysed as a cultural landscape of individual qualities and forms (plane, tombstones, fences, greenery).

At the turn of the 19th $\mathrm{c}$. tourism, newly born, was discovering the cultural heritage of the world. Tourists discovered, often afresh, historical and religious buildings. The $19^{\text {th }} \mathrm{c}$. also brought interest in deathspaces which resulted from changing Western attitudes to death (ARIES 1989).

The cult of the dead, which had disappeared in the Middle Ages was revived 
śmierci stanowiły od tej pory cel masowych podróży turystycznych, najczęściej o motywach poznawczych i religijnych. W XIX w. popularne były publikacje dzienników i listów z podróży do grobów i miejsc śmierci, w których autorzy zastanawiali się m.in. nad sensem życia i starali się rozwikłać tajemnicę śmierci. Na zainteresowanie poznawcze przestrzeniami śmierci miała ponadto wpływ rosnąca świadomość narodowa i historyczna mieszkańców Europy i Stanów Zjednoczonych. W konsekwencji czego śmierć stała się symbolem patriotyzmu (śmierć za ojczyznę).

Założenie w 1803 r. cmentarza Pere Lachaise w Paryżu było przełomem w organizowaniu przestrzeni cmentarzy w cywilizacji Zachodu. Dziewiętnastowieczni twórcy projektów cmentarzy pragnęli, żeby cmentarz, będący miejscem spoczynku zmarłych i pamięci o nich, był zarazem parkiem zorganizowanym dla wizyt rodzin, muzeum na otwartej przestrzeni oraz miejscem sprzyjającym zadumie.

W Anglii i w Stanach Zjednoczonych pojawiła się idea wiejskiego cmentarza ogrodu (rural cemetery), projektowanego również z myślą o żyjących, zgodnie z którą ogród umarłych łączyć miał w sobie walory krajobrazowe, zieleń i architekturę. Cmentarz na wzór ogrodu miał sprzyjać refleksji i wspomnieniom po zmarłych, jednocześnie miał być miejscem spacerów i spędzania wolnego czasu. Proces ten był szczególnie widoczny na obszarach rozrastających się gwałtownie w XIX w. miast (Boston, Nowy York, Hamburg, Wiedeń). W Stanach Zjednoczonych nawet niektóre parki miejskie nawiązywały do koncepcji cmentarza ogrodu, m.in. Central Park w Nowym Jorku powstał na wzór brooklińskiego cmentarza ogrodu Green-Wood.

W ten oto sposób przestrzeń śmierci, jaką stanowi m.in. cmentarz, nabrała zupełnie innego charakteru, odmiennego od średniowiecznego cmentarza. Cmentarz nie był już tylko miejscem anonimowego pochówku, ale stał się miejscem pamięci.

Dziewiętnastowieczny romantyzm przyniósł zainteresowanie mistycyzmem i dramatyzmem śmier-ci. Modne było odwiedzanie pól bitewnych (Wa-terloo), miejsc masowej śmierci (Pompeje), miejsc kaźni (Tower of London) i morderstw (Londyn Kuby Rozpruwacza) oraz cmentarzy i grobów (Pere Lachaise, Saint Michel, katakumby Paryża i Rzymu, piramidy egipskie). Można przyjąć tezę, że „raczkująca” w XIX w. turystyka kulturowa w znaczącym stopniu wykorzystywała przestrzenie śmierci.

Turyści przełomu XX i XXI w., podróżujący in Europe in the late $18^{\text {th }} \mathrm{c}$., and brought about a change in attitudes to death, the grave and the cemetery. Deathspaces became destinations for mass tourism, usually for cognitive or religious reasons. In the $19^{\text {th }} \mathrm{c}$. the publishing of journals and letters, where the authors had pondered on the meaning of life and tried to solve the mystery of death from journeys to graves and death sites, was popular. Interest in deathspaces was also a product of growing national and historical awareness among the inhabitants of Europe and the United States. As a consequence, death became a symbol of patriotism (dying for the homeland).

The setting up of the Pere Lachaise cemetery in Paris in 1803 was a breakthrough in the organization of cemetery space in western civilization. 19th c. cemetery designers wanted the cemetery, a resting place for the dead and where they are remembered, to also be a park for visiting families, an open air museum and a thought-provoking site.

In Britain and the United States the idea of a rural cemetery appeared, designed with the living in mind as well. According to this idea a garden of the dead was supposed to combine landscape assets, greenery and architecture. Such a cemetery was to provoke reflection and reminiscence of the dead and at the same time be a place to walk and spend free time. The phenomenon was particularly visible in rapidly developing areas in the $19^{\text {th }} \mathrm{c}$. (Boston, New York, Hamburg, Vienna). In the United States some municipal parks were even based on the concept of the rural cemetery, e.g. the design of Central Park in New York was based on Brooklyn Greenwood rural cemetery.

In this way deathspace assumed quite a new character different from the medieval cemetery. It was not only a burial place any more, but also a place of reminiscence.

$19^{\text {th }}$ c. romanticism brought a fascination with the mysticism and drama of death. It became fashionable to visit battlefields (Waterloo), places of mass death (Pompeii), places of torture (the Tower of London) and murder (Jack the Ripper's 
w ramach turystyki kulturowej, bardzo często docierają do obiektów i miejsc związanych ze śmiercią, kierując się przy tym wieloma motywami, najczęściej edukacyjnymi, patriotycznymi, poznawczymi, genealogicznymi i religijnymi, wynikającymi z ich zainteresowań.

W XX w. pojawił się jednak jeszcze jeden motyw, ściśle związany $\mathrm{z}$ potrzebą doświadczenia rozrywki poprzez doznanie uczucia strachu, przerażenia, fikcyjnego kontaktu ze śmiercią. Ten rodzaj motywu jest niewątpliwie konsekwencją rozwoju „kultury masowej” (MORIN 1965), mającej niewiele wspólnego $\mathrm{z}$ duchem romantyzmu. Zainteresowanie śmiercią $\mathrm{w}$ tym wymiarze jest wbrew pozorom dość powszechne, przejawiające się W wycieczkach do krypt, katakumb, ossuariów, starych cmentarzy oraz obiektów muzealnych prezentujących „oblicza śmierci” (np. Muzeum Madam Tissou i Lochy Strachu w Londynie, krypty kapucynów w Rzymie i Palermo, Kaplica Czaszek w Czermnej). Również obrzędy ściśle powiązane ze śmiercią stanowią obiekt zainteresowań turystów (np. Dzień Zmarłych w Meksyku, pogrzeby w Nowym Orleanie). Parady Halloween są okazją do zabawy i rozrywki, atrakcją turystyczną, w tle której widnieje śmierć.

Niewątpliwie istnieje na gruncie turystyki konflikt pomiędzy sacrum śmierci a jej współczesnym obliczem profanum. Popkulturowe obnażanie śmierci, czynienie ze śmierci obiektu zabawy i drwin (np. w parkach rozrywki), konsekwencją czego jest m.in. obdzieranie ze świętości śmierci i jej brutalizacja komiksowa i filmowa, nazwane zostało przez GORERA (1979) „pornografią śmierci".

W Polsce w ostatnich 20 latach przeżywamy wyraźny renesans śmierci. Zwiększone zainteresowanie cmentarzami jako pomnikami narodowej przeszłości i współczesności wpływa na wzrost liczby osób odwiedzających przestrzenie śmierci z motywów poznawczych i historycznych (cmentarze, obozy zagłady, wystawy portretów trumiennych). Cmentarze przestały być obiektami peryferyjnymi i tematem tabu w życiu publicznym. Stały się istotnym celem wycieczek krajoznawczych, obiektem godnym odwiedzenia, a dla części społeczeństwa również miejscem spędzania wolnego czasu.

Aktywność turystyczna jest procesem wpływającym na przemiany zachodzące w przestrzeni geograficznej, w wyniku którego kształtuje się przestrzeń turystyczna. Wykorzystanie przestrzeni śmierci na potrzeby turystyki kulturowej prowadzi do konieczności zidentyfikowania i opisania procesu przemian zachodzących pod wpływem zjawisk
London), as well as cemeteries and individual graves (Pere Lachaise, Saint Michel, the catacombs of Paris and Rome and the Egyptian pyramids). It can be assumed that the early cultural tourism of the $19^{\text {th }}$ century exploited deathspace to quite a large extent.

At the turn of the $21^{\text {st }} \mathrm{c}$. cultural tourists often reach buildings and sites connected with death, and they are guided by many different motives, usually educational, patriotic, cognitive, genealogical or religious.

In the $20^{\text {th }} \mathrm{c}$. yet another motive appeared, strictly connected with the need for entertainment through an experience of fear, dread and a fictional contact with death. Such a motive is undoubtedly a consequence of the 'mass culture' development (MORIN 1965) which has little to do with the spirit of romanticism. This kind of interest in death is quite common and shows itself in trips to catacombs, ossuaries, old cemeteries and museums presenting the 'faces of death' (e.g. Madame Tussaud's Museum and London Dungeon, the capuchin crypts in Rome and Palermo, the Chapel of Skulls in Czermna). Death rituals are also of interest to tourists (e.g. the Day of the Dead in Mexico, funerals in New Orleans). Halloween parades are an opportunity to have fun, an attraction with death in the background.

Naturally there is a conflict between the sacrum of death and its contemporary profanum face in tourism. The pop-cultural exposure of death, an object of fun and mockery (e.g. in funfairs) stripping it of its holiness, its brutalization in comic books and films, have been described as 'death pornography' by GORER (1979).

In the last 20 years in Poland a clear renaissance of interest in death has been observed. The growing interest in cemeteries as monuments of national past and present has increased the number of people who visit deathspaces for cognitive and historical reasons (cemeteries, death camps, gravestone portrait exhibitions). Cemeteries have stopped being peripheral places or a taboo. They have become important destinations, well worth visiting, and for some a place where they 
turystycznych, wpływających na poszerzanie przestrzeni turystycznej o nowe przestrzenie pierwotnie uważane za nieturystyczne.

Współczesne zainteresowanie przestrzeniami śmierci w aspekcie turystycznym wpłynęło na wyodrębnienie specyficznego rodzaju podróży o charakterze poznawczym lub poznawczo-religijnym do miejsc dokumentujących i upamiętniających śmierć, odbywających się w ramach turystyki kulturowej - tzw. tanatoturystyki.

Przestrzenie śmierci są często atrakcją turystyczną i składową produktu turystycznego. Potwierdzeniem tej tezy jest bytność przestrzeni śmierci w przewodnikach turystycznych, ofertach biur podróży, materiałach promujących walory turystyczne miejsca. Przykładowo, Cmentarz Pere Lachaise w Paryżu odwiedza rocznie ok. 800 tys. turystów (tab. I).

T a b e I a I. Wielkość ruchu turystycznego na wybranych cmentarzach

\begin{tabular}{|l|c|}
\hline \multicolumn{1}{|c|}{ Cmentarz } & $\begin{array}{c}\text { Liczba odwiedzających } \\
\text { w ciagu roku w tys. }\end{array}$ \\
\hline Pere Lachaise - Paryż & 800 \\
\hline Żydowski - Praga (Josefov) & 670 \\
\hline Green Wood - Nowy Jork & 500 \\
\hline Campo Santo - Piza & 210 \\
\hline St Louis - Nowy Orlean & 100 \\
\hline Highgate Cemetery - Londyn & 38 \\
\hline Żydowski - Warszawa (ul. Okopowa) & 20 \\
\hline Żydowski - Łódź & 15 \\
\hline
\end{tabular}

Ż r ó d ło: Opracowano na podstawie danych z cmentarzy.

Przestrzeń sepulkralna, zaliczana do grupy walorów antropogenicznych (walorów kulturowych, dóbr kultury, historycznych, krajoznawczych czy religijnych), jest częścią dziedzictwa kulturowego. Wpisanie obiektu na Listę Światowego Dziedzictwa UNESCO stanowi pewien wyznacznik jego wartości i stopnia atrakcyjności turystycznej. Na Liście znajdują się co najmniej 34 obiekty sepulkralne (tab. II).

Z pewnością wykorzystanie przestrzeni śmierci na potrzeby turystyki jest kontrowersyjne, ale nie jest niczym nowym. Problem polega jednak na interpretacji tych przestrzeni, sposobie ich turystycznego wykorzystania przy jednoczesnym poszanowaniu sacrum, co wydaje się być zagrożone przez nieograniczony rozwój „kultury masowej”, której nośnikiem jest m.in. turystyka. spend their free time.

Tourism activity is a process which brings changes to geographical space and thus creates tourism space. The exploitation of deathspace for the purposes of cultural tourism leads to the necessity to identify and describe the changes induced by tourism and enlarging tourism space into areas originally considered nontourist.

Contemporary interest in death caused a new particular type to emerge known as thanatourism. Tourists travel to sites which document and commemorate death for cognitive or religious reasons.

Deathspaces are often tourist attractions and elements of the tourism product. This is confirmed by the presence of deathspaces in tourist guidebooks, tourist office offers, and materials promoting the tourism assets of a given destination. The Pere Lachaise cemetery in Paris e.g. is visited by about 800000 tourists every year (table I).

$\mathrm{T}$ a b I e I. Tourism activity at selected cemeteries

\begin{tabular}{|l|c|}
\hline \multicolumn{1}{|c|}{ Cemetery } & $\begin{array}{c}\text { Number of visitors per year } \\
\text { (in thousands) }\end{array}$ \\
\hline Pere Lachaise - Paris & 800 \\
\hline Jewish - Prague & 670 \\
\hline Green Wood - New York & 500 \\
\hline Campo Santo - Pisa & 210 \\
\hline St Louis & 100 \\
\hline Highgate Cemetery - London & 38 \\
\hline Jewish - Warsaw (Okopowa Street) & 20 \\
\hline Jewish - Łódź & 15 \\
\hline
\end{tabular}

S o u r c e: Based on cemetery statistics.

Sepulchral space, regarded as an anthropogenic asset (cultural assets, places with cultural, historical, landscape or religious value) is part of the cultural heritage. If a site is put on the UNESCO World Heritage List, it demonstrates its value and tourist attractiveness. The List includes at least 34 sepulchral items (table II).

Certainly, exploiting death for tourism purposes is controversial, but it is not in fact new. The problem, however, lies in the interpretation of these spaces, and the way they are exploited so as to keep the sacrum element intact. This seems at risk due to the unlimited development of mass culture. 
T a b e I a II. Cmentarze i grobowce wpisane na Listę Światowego Dziedzictwa Kulturalnego UNESCO

\begin{tabular}{|c|c|}
\hline Obiekt & Lokalizacja \\
\hline Grobowiec Tracki & Kazanlak - Bułgaria \\
\hline Starożytny cmentarz Memphis (piramidy i grobowce) & Giza-Dahshur - Egipt \\
\hline Starożytny cmentarz w Dolinie Królów & Teby - Egipt \\
\hline Cmentarz przycerkiewny (cerkiew św. Piotra i Pawła) & Stari Ras - Serbia i Czrnogóra \\
\hline Wczesnochrześcijańskie katakumby Abu Mena & Abu Mena - Egipt \\
\hline Cmentarz (Grobowiec Askii) & Gao - Mali \\
\hline Fenickie królewskie grobowce & Pafos - Cypr \\
\hline Prehistoryczny cmentarz (kompleks podziemi Hal Saflieni) & Paola - Malta \\
\hline Stalle i królewskie grobowce Królestwa Aksum & Aksum - Etiopia \\
\hline Cmentarz (historyczne zabytki Thatty) & Thatta - Pakistan \\
\hline Starożytny cmentarz Aliscamps (rzymskie zabytki Arles) & Arles - Francja \\
\hline Grobowiec Tracki & Svesztari (Razgrad) - Bułgaria \\
\hline Starożytny cmentarz (obszar miasta Kairuan) & Kairuan - Tunezja \\
\hline Grobowce Królów Bugandy & Kasubi (Kampala) - Uganda \\
\hline Grobowiec Humajuna & Delhi - Indie \\
\hline Cmentarz Konfucjusza (kompleks rezydencjonalny rodziny Kong) & Qufu - Chiny \\
\hline Cmentarz Skogskyrkogarden (Leśny Cmentarz) & Sztokholm - Szwecja \\
\hline Podziemne grobowce Tierradentro & Tierradentro - Kolumbia \\
\hline Królewskie grobowce (kurhany) & Vergina - Grecia \\
\hline Neolityczny grobowiec & Orkany - Szkocja \\
\hline Cesarskie Grobowce Dynastii Qing & Nankin - Chiny \\
\hline Cmentarz Campo Santo (Piazza del Duomo) & Piza - Włochy \\
\hline Cmentarz wczesnochrześcijański & Pecs (Sopianae) - Wegry \\
\hline Prehistoryczne cmentarze (dolmeny) & Gochan, Hwasun, Gonghwa - Korea Pd \\
\hline Skalne grobowce (Klasztor Grzegorza i Dol. Azat) & Goght - Armenia \\
\hline Cesarskie Grobowce Dynastii Ming & Pekin - Chiny \\
\hline Cmentarz żydowski (Dzielnica Żydowska i bazylika św. Prokopiusa) & Trebic-Czechy \\
\hline Starożytne grobowce - piramidy Napata & Meroe - Sudan \\
\hline Cmentarz Nowodziewiczy (Klasztor Nowodziewiczy) & Moskwa - Rosja \\
\hline Grobowce Starożytnego Królestwa Koguryo & Liaoning, Ji'an, Jilin - Chiny \\
\hline Kompleks grobowców Kogurjo & Phenian - Korea Pn. \\
\hline Prehistoryczne grobowce Tamgaly & Ałmata - Kazakhstan \\
\hline Starożytne cmentarze Etrusków & Cerveteri, Tarquinia -Włochy \\
\hline Starożytny skalny cmentarz & Pantalica - Sycylia - Włochy \\
\hline
\end{tabular}

Ż r ó d ł o: Opracowano na podstawie danych UNESCO (stan na koniec 2005 r.).

T a b I e II. Cemeteries and tombs placed on the UNESCO World Heritage List

\begin{tabular}{|c|c|}
\hline Cemetery or tombstone & Location \\
\hline Thracian Tomb & Kazanlak - Bulqaria \\
\hline Memphis necropolis of pyramids and tombs & Giza-Dashshur - Egypt \\
\hline Necropolis in the Valley of Kings & Thebes - Eqypt \\
\hline Church cemetery (St Peter \& Paul Orthodox Church) & Stari Ras - Serbia and Montenegro \\
\hline Early Christian catacombs of Abu Mena & Abu Mena - Egypt \\
\hline Tomb of Askia & Gao - Mali \\
\hline Phoenician royal tombs & Paphos - Cyprus \\
\hline Prehistoric cemetery (Hal Saflieni Hypogeum) & Paola - Malta \\
\hline Stalls and royal tombs of the Kingdom of Aksum & Aksum - Ethiopia \\
\hline Cemetery (historical monuments in Thatta) & Thatta - Pakistan \\
\hline Ancient cemetery of Aliscamps (Roman historical monuments of Arles) & Arles - France \\
\hline Thracian tomb & Sveshtari (Razgrad) - Bulgaria \\
\hline Ancient Phoenician cemetery (the area of Kairouan) & Kairouan - Tunisia \\
\hline Tombs of the kings of Buganda & Kasubi (Kampala) - Uganda \\
\hline Humayun's Tomb & Delhi - India \\
\hline Confucius Cemetery (residential complex of the Kong Family) & Qufu - China \\
\hline Skogskyrkogarden Cemetery (Forest Cemetery) & Stockholm - Sweden \\
\hline Underground tombs of Tierradentro & Tierradentro - Columbia \\
\hline Royal tombs (tumuli) & Vergina - Greece \\
\hline Neolithic tomb & Orkney Islands - Scotland \\
\hline Imperial Tombs of the Qing Dynasty & Naniing - China \\
\hline Campo Santo Cemetery (Piazza del Duomo) & Pisa - Italy \\
\hline Early Christian cemetery & Pecs (Sopianae) - Hungary \\
\hline Prehistoric cemeteries (dolmens) & Gochan, Hwasun, Gonghwa - South Korea \\
\hline Cave tombs (St. Geghard Monastery and the Azat valley) & Goght - Armenia \\
\hline Imperial Tombs of the Ming Dynasty & Beijing - China \\
\hline Jewish cemetery (Jewish quarter and St Prokopius Basilica & Trebic-Czech Republic \\
\hline Ancient tombs - Napata pyramids & Meroe - Sudan \\
\hline Novodevichy Cemetery (Novodevichy Convent) & Moscow - Russia \\
\hline Tombs of the ancient Kingdom of Koguryo & Liaoning, Ji'an, Jilin - China \\
\hline Kogurio tomb complex & Phenian - North Korea \\
\hline Prehistoric tombs of Tamgaly & Alma Ata - Kazakhstan \\
\hline Ancient Etruscan cemeteries & Cerveteri, Tarquinia, - Italy \\
\hline Ancient cave cemetery & Pantalica - Sicily - Italy \\
\hline
\end{tabular}

S o u r c e: Based on UNESCO data (valid at the end of 2005). 


\section{BIBLIOGRAFIA - BIBLIOGRAPHY}

ARIÉs P., 1989, Człowiek i śmierć, PIW, Warszawa.

FRANCAVIGLIA R. V., 1971, The cemetery as an evolving cultural landscape, Annals. Association of American Geographers, 61, s. 501-509.

Gorer G., 1979, Pornografia śmierci, Teksty, 3 (45)
KNIFFEN F., 1967, Necrogeography in United States, Geographical Review, 57, s. 426-427.

MoRIN E., 1965, Duch czasu, Znak, Warszawa.

TANAŚ S., 2004, Cmentarz jako przedmiot zainteresowań geografii turyzmu, Turyzm, 9(1), s. 71-87. 